\title{
PENGARUH PELATIHAN GOAL SETTING TERHADAP EFIKASI DIRI MANAJER TINGKAT MENEGAH DI PT BAT YOGYAKARTA
}

\author{
Pratiningsih $^{1}$, Alimatus Sahrah ${ }^{2}$ \\ ${ }^{12}$ Fakultas Psikologi Universitas Mercu Buana Yogyakarta \\ 1pratiningsih@hotmail.com \\ 2alimatus_sahrah@yahoo.co.id
}

\begin{abstract}
Abstrak
Penelitian ini bertujuan untuk mengetahui pengaruh pelatihan goal setting terhadap efikasi diri manajer tingkat menengah. Hipotesis yang diajukan ada perbedaan efikasi diri manajer tingkat menengah yang mendapat pelatihan goal setting (kelompok eksperimen) dengan manajer tingkat menengah yang tidak mendapat pelatihan goal setting (kelompok kontrol). Desain eksperimen yang digunakan yaitu pretes-posttes control group design. Subjek penelitian adalah manajer tingkat menengah Di PT BAT Yogyakarta sebanyak 16 orang Metode pengumpulan data dalam penelitian ini menggunakan skala efikasi diri, adapun analisis data dilakukan dengan menggunakan statistik Mann Whitney Test dan Wilxocon Signed Ranks Test. Hasil analisis data menunjukkan ada perbedaan efikasi diri antara kelompok eksperimen dengan kelompok kontrol, dilihat dari selisih skor pretest dan post test (Gained Score) Hasil Gained Score ditemukan nilaiZ= $-3,464$ dan $p<0,01$. Hasil analisis tersebut menunjukkan bahwa ada perbedaan tingkat efikasi diri antara kelompok eksperimen yang diberi perlakuan dengan kelompok kontrol yang tidak diberi perlakuan, selanjutnya digunakan analisis Wilxocon untuk melihat perbedaan skor pretes dan posttest pada kelompok eksperimen. Hasilnya menunjukkan ada perbedaan hasil uji beda skor pretes - posttest yang menunjukkan koofisiensi $Z$ sebesar $-2,747$ dan $p<0,01$. Hal ini berarti ada perbedaan tingkat efikasi diri pada manager tingkat menengah pada kelompok eksperimen sesudah pelatihan goal setting. Jadi dapat disimpulkan bahwa pelatihan goal setting berpengaruh terhadap efikasi diri manager tingkat menengah.
\end{abstract}

Kata Kunci: pelatihan goal setting, efikasi diri, manajer tingkat menengah

\section{EFFECT OF GOAL-SETTING TRAINING ON SELF-EFFICACY AMONG MIDDLE MANAGERS IN PT BAT YOGYAKARTA}

\author{
Pratiningsih $^{1}$, Alimatus Sahrah ${ }^{2}$ \\ ${ }^{12}$ Psychology Faculty of Mercu Buana University of Yogyakarta \\ ${ }^{1}$ pratiningsih@hotmail.com, \\ 2alimatus_sahrah@yahoo.co.id
}

\begin{abstract}
The objective of this study is to examine the effect of goal-setting training on self-efficacy among middle managers. The hypothesis developed in the study was that there is difference in self-efficacy among middle-managers given the goal-setting training (experimental group) and not given the training (control group). The study was conducted by using a quantitative method with a pretest-posttest control group design. Subjects of the study were 16 middle managers in PT BAT Yogyakarta. The data used were collected using a self-efficacy scale. The data collected were analyzed using Mann Whitney test and Wilxocon Signed Ranks test. The results of analysis showed that there was difference in self-efficacy among middle managers between the experimental group and the control group viewed from difference in pretest-posttest score (Gained Score) with $Z=-3.464$ and $p<0.05$. The results showed that there was difference in self-efficacy among middle managers given the goal-setting training in the experimental group and not given the training in the control group. Moreover, Wilxocon analysis was carried out for difference in
\end{abstract}


pretest-posttest score among middle managers in the experimental group. The results showed that there was difference in pretest-posttest score with $Z=-2.747$ and $p<0.05$. This means that there was difference in self-efficacy among middle managers given the goal-setting training in the experimental group. Thus, it can be concluded that the goal-setting training had a significant effect on self-efficacy among middle managers.

Keywords: goal-setting training, self-efficacy, middle managers

\section{PENDAHULUAN}

Indonesia merupakan salah satu negara yang sedang berkembang, hal ini juga akan diikuti oleh tuntutan terhadap sumber daya manusia yang berkualitas serta mampu bersaing di era globalisasi sekarang ini, kondisi persaingan tersebut menuntut untuk dilakukan usaha dan strategi agar perusahaan dapat bertahan dengan beragam kompetitor baik pada usaha sejenis maupun kompetitor dibidang yang lainnya.

Peran seorang manajer sangat dibutuhkan sebagai perpanjangan tangan dari perusahaan untuk bisa menjalankan roda organisasi, manajer harus mengetahui kemana arah yang akan dituju oleh perusahaan. Menurut Kartono (2002) manajer bertanggung jawab dalam penentuan arah organisasi dan memiliki otoritas tertinggi untuk menggerakan semua karyawan pada sasaran perusahaan, manajer turut andil sebagai penentu dalam sukses atau gagalnya organisasi.

Kesuksesan ataupun kegagalan yang dialami organisasi sebagian besar ditentukan oleh kualitas kepemimpinan yang dimiliki oleh orang-orang yang diserahi tugas untuk memimpin dalam organisasi yang bersangkutan, hal ini sesuai dengan pendapat yang dikemukakan Suwandi (Suranta, 2002) bahwa keberadaan pemimpin dalam perusahaan adalah sangat penting karena ia memiliki peranan yang sangat strategis dalam mencapai tujuan perusahaan.

Seorang manajer harus mampu menjalankan tugasnya dengan sebaik-baiknya agar dapat mencapai tujuan organisasi yang telah ditetapkan, ia harus mampu dan meyakini bahwa dirinya bisa bekerja dengan orang lain agar mencapai berbagai hasil, harus mampu malakukan pengintegrasian berbagai sumber daya dan tugas untuk mencapai berbagai tujuan organisasi yang telah ditentukan, serta meyakini bahwa ia mampu melakukan berbagai kegiatan untuk menjamin bahwa tujuan kelompok kerjanya dapat dicapai.

Seorang manejer dituntut untuk memiliki kompetensi yang meliputi pengetahuan, keterampilan dan etika. Pengetahuan yang meliputi bidang teknis dan bidang manajerial. Seorang manejer harus memahami proses bisnis yang dipimpinnya dan mempunyai pengetahuan tentang bidang manajerial agar mampu menjalankan perusahaan dengan baik. Pengetahuan dapat diperoleh dari pendidikan formal maupun pendidikan non formal.

Kompetensi manajer ada tiga yakni pertama adalah management skill yakni kemampuan manajemen merupakan kemampuan dalam menerapkan fungsi-fungsi manajemen POAC (Planning, organizing, 
actuating, and controlling) dan kemampuan untuk menyelesaikan masalah yang muncul. Kedua yakni technical skill, kemampuan teknis merupakan kemampuan dalam menggunakan alat, termasuk alat bantu (tools), menerapkan prosedur operasional standard dan pengetahuan teknis yang berkaitan dengan bidang kerja. Manajer harus memiliki keahlian yang cukup dalam bidang kerjanya. Human Skill, kemampuan manusiawi merupakan kemampuan untuk bekerjasama dengan orang lain dan memotivasi orang lain baik sebagai individu maupun kelompok. Ketiga conceptual skills, kemampuan konseptual merupakan kemampuan untuk mengkoordinasi dan memadukan berbagai kepentingan, selain itu manajer harus mempunyai konsep yang jelas, terarah, terukur untuk menjalankan tugasnya

Setiap jenjang manajemen membutuhkan pengetahuan dan keterampilan yang berbeda. Manajer puncak lebih membutuhkan kemampuan konseptual dibandingkan kemampuan teknis. Manajer menengah membutuhkan kemampuan konseptual dan teknis secara berimbang, sedangkan manajer tingkat bawah lebih membutuhkan keterampilan teknis. Ketiga manajer tersebut membutuhkan keyakinan yang tinggi didalam melaksanakan tugasnya, sehingga tujuan perusahaan yang tercantum dalam visi dan misi dapat tercapai dengan baik Keyakinan seseorang terhadap kemampuannya untuk melakukan perilaku tertentu disebut dengan efikasi diri (Bandura, 1997). Efikasi ini dapat dikembangkan dan dipelajari oleh individu, keyakinan yang kuat akan kemampuan diri menyebabkan seseorang terus berusaha agar tujuannya tercapai, namun keyakinan akan kemampuan diri akan cenderung mengurangi usahanya bila menemui masalah, baik yang datang dari luar dirinya maupun dari dalam dirinya.

Efikasi diri merupakan aspek penting yang harus dimiliki dalam berkerja karena berpengaruh pada keberhasilan pekerjaan, lebih lanjut Bandura 1997, menyebutkan bahwa efikasi kerja mempengaruhi apakah seseorang berpikir inkonsisten atau strategis, optimis atau pemisimis, yang dapat mempengaruhi tindakan yang akan dipilih, seberapa besar usaha yang dilakukan, seberapa besar hasil yang diharapkan, serta seberapa lama mampu bertahan dalam menghadapi rintangan, seberapa banyak stress dan depresi yang mereka alami dalam menghadapi tuntutan lingkungan kerja.

Robin (1998) mengatakan efikasi diri merupakan kepercayaan seseorang terhadap kemampuannya untuk dapat melaksanakan tugas dengan baik. Semakin seseorang mempunyai efikasi diri tinggi, maka individu tersebut semakin mempunyai kepercayaan diri yang tinggi terhadap kemampuannya untuk dapat menyelesaikan tugas dengan baik dan sebaliknya

Salah satu aspek dalam diri individu yang memungkinkan terjadinya perubahan penentuan tujuan adalah efikasi diri karyawan, Locke, (Ramadanti, 2010) mengemukakan bahwa efikasi memiliki empat mekanisme yaitu mengarahkan tujuan, upaya mengatur tujuan, menyusun strategi dan rencana tujuan. 
Menentukan tujuan dalam motivasi kerja pada setiap individu dapat berubah-ubah, bisa naik, bisa juga turun. Perubahan tersebut bisa disebabkan karena faktor individu itu sendiri atau faktor lingkungan kerja individu. Salah satu aspek dalam diri individu yang memungkinkan terjadinya perubahan penentuan tujuan dalam bekerja adalah effikasi diri karyawan.

PT. BAT merupakan salah satu perusahaan yang sedang berkembang yang bergerak di bidang jasa pariwisata khususnya pelestarian hewan dan tumbuhan dan mengalami perubahan budaya organisasi yakni yang tadinya berbentuk yayasan dan berubah menjadi sebuah PT, perubahan ini diikuti oleh tuntutan akan adanya sumber daya manusia yang berkualitas dan handal serta memiliki kemampuan bekerja secara cepat, tepat dan dapat fokus mencapai hasil yang diinginkan perusahaan, karyawan dituntut untuk menghadapi perubahan tersebut, dengan adanya peralihan dari Yayasan menjadi sebuah PT membuat karyawan beradaptasi pada kebijakan dan peraturan yang baru, yang mana perubahan ini memberi dampak pada kinerja karyawan.

Kanit maupun Kabid dituntut untuk melakukan tugas-tugas manajerial yakni menjalankan fungsi manajemen yang meliputi kegiatan perencanaan, pengorganisasian, pengendalian dan pengarahan serta menjalankan fungsi pengawasan. Pada kenyataannya sebagian besar Kanit maupun Kabid merasa ragu dan mengalami kesulitan membuat perencanaan program unit atau bidangnya. Hal ini diperparah oleh tidak adanya pelatihan khusus bagi Kanit dan Kabid, khususnya tentang manajerial sehingga para Kanit maupun Kabid merasa tertekan jika harus membuat perencanaan kerja terutama pada bagian operasional. Pekerjaan dilakukkan hanya berdasarkan tugas rutin saja, yang terdapat pada buku uraian tugas yang menjadi pegangan bagi kanit dan kabid, dalam bekerja kabid dan kanit tidak membuatkan targettarget waktu pencapaian kerja, hal ini akan berdampak pada kinerja bawahan yang lamban dalam menyelesaikan suatu pekerjaan, tugas yang diberikan kepada bawahan tidak memiliki batas waktu untuk menyelesaikan suatu pekerjaan sehingga staf bekerja dengan lama, selain itu pada fungsi pengawasan manajer merasa kurang yakin bisa memberikan bimbingan dan arahan kepada bawahan agar dapat bekerja dengan efektif dan efisien. Manajer cenderung membiarkan saja kinerja bawahan yang tidak sesuai dengan standar, sikap enggan untuk melakukan teguran kepada bawahan jika bawahan bekerja lamban dan lama sehingga pekerjaan yang dihasilkan tidak sesuai dengan yang diharapkan oleh perusahaan dan tidak mencapai target yang diinginkan perusahaan.

Oleh karena besarnya peran manajer menengah dalam mencapai target atau sasaran kerja di unit atau bidangnya, maka perlu dilakukan upaya lebih lanjut untuk mengatasi permasalahan tersebut sehingga ditemukan intervensi yang tepat untuk mengatasinya. Pelatihan/training merupakan salah satu intervensi yang bisa digunakan dalam dunia kerja, pelatihan adalah suatu kegiatan yang digunakan oleh perusahaan atau institusi untuk 
memfasilitasi proses belajar belajar untuk mencapai kompetesnsi dalam pekerjaannya. (Noe, 2005) kompetensi ini meliputi pengetahuan, keterampilan dan perilaku yang dianggap penting untuk mencapai kinerja yang tinggi. Usaha meningkatkan kemampuan kerja karyawan dapat dilakukan dengan menambah pengetahuan, keterampilan dan mengubah sikap sehingga dapat menjadi kekayaan organisasi yang paling berharga, karena dengan segala potensi yang dimilikinya, karyawan dapat dilatih dan dikembangan sehingga dapat lebih berdayaguna dan berprestasi optimal guna mencapai tujuan organisasi.

Beberapa penelitian menunjukkan bahwa terdapat pengaruh positif pelatihan goal setting terhadap peningkatan efikasi diri. Hasil penelitian Spieker dan Hinz 2004, menyatakan bahwa individu yang menetapkan tujuan dalam bekerja akan dapat meningkatkan efikasi diri, sehingga kinerjanya akan meningkat. Senada dengan hal tersebut, hasil penelitian Seijts, Latham, Tasa dan Latham (Sutama 2012), juga menunjukkan adanya peningkatan efikasi diri pada individu yang secara spesifik menetapkan tujuan. Pada penelitian Gibson(2001), mengatakan bahwa pelatihan penetapan tujuan (goal setting)dapat meningkatkan efikasi diri dan efektifitas individu. Hasil penelitiannya pada perawat Rumah Sakit menunjukkan bahwa perawat yang diberi pelatihan penetapan tujuan memiliki efikasi diri dan efektivitas diri yang tinggi dibandingkan dengan perawat yang tidak diberikan pelatihan penetapan tujuan.
Ditambah lagi dalam penelitian Suryandari (2011), yang hasilnya menunjukkan bahwa ada pengaruh signifikan pelatihan goal setting terhadap efikasi diri wiraniaga, terutama dalam hal mencapai target penjualan, selanjutnya penelitian penelitian Lawrence dan Smith (Arsanti, 2009) juga mengatakan bahwa kinerja individu akan meningkat apabila mereka bekerja pada kondisi dengan penetapan tujuan daripada tanpa ada penetapan tujuan, dengan demikian keberadaan penetapan tujuan (goal setting) sangatlah penting ditempat kerja

Berdasarkan beberapa penelitian di atas, intervensi yang akan peneliti lakukan yakni pemberian intervensi dalam bentuk pelatihan goal setting sesuai dengan pengertiannya bahwa goal setting merupakan panduan atau acuan yang akan mengarahkan individu dalam bertindak dan bekerja diwaktu akan datang untuk mencapai hasil yang diinginkan. Pelatihan ini bertujuan untuk memberikan pemahaman dan pengetahuan kepada manajer tingkat menengah bahwa menyusun tujuan dengan jelas itu sangatlah penting dikarenakan dapat memberikan arah dan fokus yang lebih terperinci bagi manajer tingkat menengah didalam melaksanakan tugas manajerialnya khususnya kemampuan manajemen skill, sehingga dalam membuat perencanaan program kerja manajer tingkat menengah lebih yakin serta tidak merasa tertekan didalam merancang program kerja unit atau bidangnya, manajer dapat membuat program dengan spesifik, jelas, dapat terukur, mudah diraih, dan berfokus pada tujuan yang 
ingin dicapai sesuai dengan kemampuan dan keterbatasan dirinya, selain itu melalui pelatihan goal setting ini diharapkan manajer dapat menentukan sikap dan tindakannya, serta merasa mantap disaat harus mengambil keputusan, dan mampu menghadapi tugas yang beragam, dengan merasa yakin terhadap kemampuan yang dimiliki, karena jika dihadapkan pada tugas-tugas yang sulit, dan tugas yang beragam manajer tingkat menengah dapat lebih yakin dalam menentukan sikap untuk mengabil tindakan, dalam menjalankan perannya sebagai seorang manajer tingkat menengah.

\section{METODE}

Variabel tergantung yang digunakan dalam penelitian ini adalah efikasi diri dan sebagai variabel bebas adalah pelatihan goal setting

1. Variabel Tergantung : Efikasi diri

Efikasi diri adalah keyakinan dalam diri seseorang bahwa dirinya memiliki kemampuan untuk melakukan sesuatu sehingga membentuk perilaku/sikap tertentu yang tepat dan mencapai tujuan yang diinginkan. Dalam penelitian ini yang diteliti adalah efikasi diri yang spesifik yakni mengenai keyakinan diri manajer tingkat menengah terhadap kemampuan yang dimilikinya untuk menentukan sikap atau tindakan didalam melaksanakan tugas manajerialnya terutama dalam hal manajemen skill.Pengukuran efikasi diri manajer menggunakan tiga dimensi efikasi diri dari Bandura (1997) yaitu magnitude (tingkatan kesulitan tugas), generality (luas bidang tugas), dan strength.(tingkat kemantapan keyakinan).

2. Variabel Bebas/ Eksperimen : Pelatihan goal setting

Pelatihan Goal setting adalah serangkaian metode yang terstruktur dan terencana guna mengembangkan kemampuan untuk dapat memiliki tujuan guna mencapai keberhasilan secara langsung dan terfokus pada permasalahan ditempat bekerja. Penetapan tujuan (goal setting) adalah panduan atau acuan yang akan mengarahkan individu dalam bertindak dan bekerja yang menggambarkan keadaan ideal ingin dicapai diwaktu yang akan datang atau menunjukkan rencana untuk mencapai hasil yang diinginkan. Adapun materi pelatihan yang akan digunakan mengacu pada lima dimensi goal setting menurut Kreitner dan Kinicki (2001) yakni:

a. Goal Difficulty (tingkat kesulitan tujuan), merupakan gambaran jumlah usaha yang digunakan untuk mencapai tujuan.

b. Goal Specificity (spesifikasi tujuan) merupakan gambaran yang berkaitan bahwa tujuan dapat dihitung secara kuantitas. Tujuan yang sulit dan spesifik akan menuntun pencapaian kinerja yang berkaitan bahwa tujuan dapat dihitung secara kuantitas.

c. Feedback (umpan balik) merupakan pemberian informasi kepada seseorang mengenai apa yang dikerjakannya dan apa yang diharapkannya sehingga mereka dapat menghubungkan energinya secara bersamaan. Umpan balik memberikan informasi yang 
berguna untuk menyesuaikan dengan arahan usaha, dan strategi untuk mencapai tujuan.

d. Participation (partisipasi) karyawan harus diikutsertakan dalam menyusun tujuan sehingga mereka tahu bagaimana strategi untuk penyelesaiannya.

e. Goal Commitment (komitmen tujuan) merupakan keinginan seseorang untuk mencapai tujuan.

Subjek penelitian adalah karyawan di PT BAT, subjek ditentukan yaitu karyawan yang menduduki posisi manajer tingkat menengah (Kepala unit dan Kepala bidang) dan memiliki masa kerja lebih dari 1 tahun. Subjek penelitian dibagi menjadi dua kelompok, yaitu kelompok eksperimen yang mendapatkan pelatihan goal setting dan kelompok kontrol yang tidak mendapatkan pelatihan goal setting.

Penentuan subjek dilakukan dengan melakukan seleksi awal menggunakan skala efikasi diri kepada karyawan manajerial yang berjumlah 28 orang (Kanit dan Kabid). Karyawan yang dilibatkan sebagai subjek penelitian adalah karyawan yang memiliki skor efikasi diri dalam kriteria rendah dan sedang, kemudian subjek dibagi menjadi dua kelompok yakni subjek yang akan mengikuti pelatihan (kelompok eksperimen) dan subjek yang tidak diberikan pelatihan (kelompok kontrol). Pembagian kedua kelompok eksperimen dan kelompok kontrol akan dilakukan secara random. Berikut ini tabel kategorisasi skor efikasi diri:
Tabel 1. Kategori data dan distribusi skor efikasi diri

\begin{tabular}{ccc}
\hline Pedoman & Skor & Kategorisasi \\
\hline$X \geq(\mu+$ & $X \geq 176$ & Tinggi \\
$1 . S D)$ & & \\
$(\mu-1 . S D) \leq$ & $113 \leq 176$ & Sedang \\
$X<(\mu+$ & & \\
$1 . S D)$ & & \\
$X<(\mu-1$. & $X<112$ & Rendah \\
SD $)$ & & \\
\hline
\end{tabular}

Berdasarkan pretes yang telah dilakukan kepada 28 orang subjek. Hasilnya 16 orang memiliki efikasi diri dengan kategorisasi skor sedang dan 12 orang efikasi diri dengan kategorisasi skor tinggi sedangkan yang kategorisasi skor rendah 0 (tidak ada). Selanjutnya 16 orang subjek di bagi menjadi 2 kelompok yakni 8 orang subjek menjadi kelompok eksperimen (diberikan pelatihan) dan 8 orang subjek menjadi kelompok kontrol ( tidak diberikan pelatihan).

\section{Metode Pengumpulan Data}

Pengumpulan data dilakukan dengan menggunakan skala efikasi diri. Skala merupakan alat ukur psikologis berupa kumpulan peryataan sikap yang disusun sedemikian rupa sehingga respon seseorang terhadap peryataan tersebut dapat diberikan skor dan kemudian dapat diinterpretasikan (Azwar, 1998). Dalam penelitian ini peneliti menggunakan tiga dimensi efikasi diri dari Bandura (1997) yaitu

a. Demensi magnitude ( tingkatan kesulitan tugas), dimensi ini mengacu pada taraf kesulitan tugas yang diyakini individu akan mampu mengatasinya.

b. Dimensi Generality (luas bidang tugas), dimensi ini mengacu pada variasi situasi di 
mana penilaian tentang efikasi diri dapat diterapkan. Seseorang dapat menilai dirinya memiliki efikasi pada banyak aktifitas atau pada aktivitas tertentu saja.

c. Dimensi Strength (tingkat kemantapan keyakinan), dimensi ini terkait dengan kekuatan dari efikasi diriseseorang ketika berhadapan dengan tuntutan tugas atau suatu permasalahan.

Skala efikasi diri ini disusun dari teori Bandura (1997) dengan menggunakan model Likert dengan 5 pilihan jawaban yaitu Sangat Sesuai (SS), Sesuai (S), Ragu-ragu (R), Tidak Sesuai (TS), dan Sangat Tidak Sesuai (STS) dengan jumlah pertanyaan sebanyak 48 untuk variable tergantung dan dibagi atas dua jenis pertanyaan yaitu peryataan favorable dan pernyataan unfavorable. Peryataan favorable jika isi nya mendukung, atau menunjukkan ciri adanya atribut yang diukur, sedangkan unfavorable jika isi nya tidak mendukung tidak memihak atau tidak menunjukkan adanya ciri adanya atribut yang diukur. (Azwar, 2010)

\section{Rancangan penelitian}

Penelitian ini dilakukan dengan penelitian eksperimen kuasi yaitu the untreated control group design with dependent pretest-posttest (Shadies, Cook, Campbell, 2002). Dalam desain ini kelompok subjek akan dibagi dua dan akan mendapat pengukuran sebelum dan sesudah pemberian perlakuan/ manupulasi. pre test-post tes adalah pengukuran yang dilakukan secara berulang, pada pra dan paska diberikan manupulasi. Kelompok kontrol adalah yang tidak diberi manipulasi berupa pelatihan, kelompok eksperimen adalah kelompok yang diberi manupulasi berupa pelatihan.

$\begin{array}{cccc}\text { KE } & \text { O1 } & \text { X } & \text { O2 } \\ \text { KK } & \text { O1 } & - & \text { O2 }\end{array}$

Keterangan

KE : Kelompok Ekperiman (kelompok yang mendapatkan perlakuan)

KK : Kelompok Kontrol (kelompok yang tidak mendapat perlakuan)

$\mathrm{R} \quad$ : Random

$\mathrm{X}$ : Pemberian manupulasi/perlakuan

O1 : Pengukuran variabel dependen sebelum maipulasi (pre -tes)

$\mathrm{O} 2$ : Pengukuran variabel dependen setelah manipulasi (post-test)

\section{Analisis Data}

Analisis data yang digunakan dalam penelitian ini adalah analisis kuantitatif yaitu Mann Whitney Test yakni untukmenguji perbedaan di antara dua kelompok data yang tidak berhubungan (berasal dari subjek yang berbeda). Selanjutnya diuji lagi dengan menggunakan Wilcoxon signed ranks yakni untuk menguji perbedaan di antara dua kelompok data yang berhubungan (berasal dari subjek yang sama) yakni untuk mengetahui apakah ada perbedaan tingkat efikasi diri pada kelompok eksperimen antara sebelum dan setelah pelatihan goal setting. Analisis selengkapnya menggunakan Stastical Product and Servise Solution (SPSS) 17 for Windows.

\section{HASIL DAN PEMBAHASAN}

Berdasarkan data yang didapat membuktikan bahwa hipotesis yang diajukan dalam penelitian ini diterima, dimana kelompok manajerial yang mendapatkan pelatihan goal settingmengalami peningkatan 
efikasi diri sedangkan untuk kelompok manajerial yang tidak diberikan pelatihan tidak menunjukkan adanya peningkatan efikasi diri.

Hasil analisis data menunjukkan ada perbedaan efikasi diri antara kelompok eksperimen dengan kelompok kontrol, dilihat dari selisih skor pretest dan post test (Gained Score). Hasil Gained Score ditemukan nilai Z= $-3,464$ dan $\mathrm{p}=0,001(\mathrm{p}<0,01)$. Hasil analisis tersebut menunjukkan bahwa ada perbedaan tingkat efikasi diri antara kelompok eksperimen yang diberi perlakuan dengan kelompok kontrol yang tidak diberi perlakuan, selanjutnya digunakan analisis Wilxocon untuk melihat perbedaan skor pretes, dan posttest pada kelompok eksperimen. Hasilnya menunjukkan ada perbedaan hasil uji beda skor pretes - posttest yang menunjukkan koofisiensi Z sebesar -2,747 p =0,006 ( $\mathrm{p}<$ $0,01)$. Hal ini berarti ada perbedaan tingkat efikasi diri pada manajer tingkat menengah pada kelompok eksperimen sesudah pelatihan goal setting. Jadi dapat disimpulkan bahwa pelatihan goal setting berpengaruh terhadap efikasi diri manajer tingkat menengah.

Beberapa penelitian menunjukkan bahwa terdapat pengaruh positif pelatihan goal setting terhadap peningkatan efikasi diri. Hasil penelitian Spieker dan Hinz (2004), menyatakan bahwa individu yang menetapkan tujuan dalam bekerja, dapat meningkatkan efikasi diri, sehingga kinerja akan meningkat. Selain itu dalam penelitian Lawrence dan Smith (Arsanti, 2009) juga mengatakan bahwa kinerja individu akan meningkat apabila mereka bekerja pada kondisi dengan penetapan tujuan daripada tanpa ada penetapan tujuan, dengan demikian keberadaan penetapan tujuan (goal setting) sangatlah penting ditempat kerja. Hal ini juga diperkuat dengan pendapat Gibson (2001) yang menyatakan bahwa penetapan tujuan dan efikasi diri yang tinggi dalam diri individu akan mempengaruhi kinerja individu tersebut untuk bekerja dengan lebih baik.

PT. BAT merupakan salah satu perusahaan yang sedang berkembang yang bergerak di bidang jasa pariwisata khususnya pelestarian hewan dan tumbuhan dan mengalami perubahan budaya organisasi yakni yang tadinya berbentuk yayasan dan berubah menjadi sebuah PT, perubahan ini diikuti oleh tuntutan akan adanya sumber daya manusia yang berkualitas dan handal serta memiliki kemampuan bekerja secara cepat, tepat dan dapat fokus mencapai hasil yang diinginkan perusahaan.

Karyawan PT BAT khususnya manajer tingkat menengah dituntut untuk menghadapi perubahan tersebut, dengan adanya peralihan dari Yayasan menjadi sebuah PT membuat karyawan beradaptasi pada kebijakan dan peraturan yang baru, yang mana perubahan ini memberi dampak pada kinerja karyawan untuk beradaptasi dengan perubahan tersebut agar bekerja dengan hasil maksimal sesuai dengan tujuan perusahaan. Menurut Kartono (2002) manajer bertanggung jawab dalam penentuan arah organisasi dan memiliki otoritas tertinggi untuk menggerakan semua karyawan pada sasaran perusahaan, manajer turut andil sebagai penentu dalam sukses atau gagalnya 
organisasi.Kesuksesan ataupun kegagalan yang dialami organisasi sebagian besar ditentukan oleh kualitas kepemimpinan yang dimiliki oleh orang-orang yang diserahi tugas untuk memimpin dalam organisasi yang bersangkutan, hal ini sesuai dengan pendapat yang dikemukakan Suwandi (Suranta, 2002) bahwa keberadaan pemimpin dalam perusahaan adalah sangat penting karena ia memiliki peranan yang sangat strategis dalam mencapai tujuan perusahaan.

Seorang manajer tingkat menengah harus mengetahui kemana arah yang akan dituju oleh perusahaan, kesukaran apa yang harus dihindari, kekuatan apa yang harus dijalankan dan bagaimana mengorganisir anggotanya dengan sebaik-baiknya untuk mencapai sasaran/tujuan sesuai visi dan misi perusahaan, oleh karena itu peran seorang manajer dalam menentukan berhasil atau tidaknya suatu program kegiatan perusahaan sangat menentukan sukses atau tidaknya perusahaan. Hal ini tentu saja harus di dukung oleh keyakinan diri manajer itu sendiri, ia harus meyakini bahwa dirinya mampu melakukan berbagai kegiatan untuk menjamin bahwa tujuan kelompok kerjanya dapat dicapai. Menurut Bandura (1997) individu dengan efikasi diri yang tinggi memiliki keyakinan terhadap kemampuan dirinya dalam menghadapi suatu situasi guna mencapai tujuan yang diharapkan. Robbins (1998) menambahkan bahwa individu yang memiliki efikasi tinggi berkeyakinan memiliki keyakinan bahwa mereka akan mampu melakukan sesuatu untuk mengubah kejadiankejadian disekitarnya dan mempunyai kepercayaan diri yang besar terhadap kemampuan untuk berhasil dalam tugas. Individu dituntut berhasil beradaptasi dengan masa transisi yang terjadi sepanjang karirnya. Begitu pula spesifikasi dalam penelitian ini yakni mengenai keyakinan diri manajer tingkat menengah terhadap kemampuan yang dimilikinya dalam menentukan sikap atau tindakan didalam melaksanakan tugas manajerialnya terutama dalam hal manajemen skill yakni kemampuan dalam menerapkan fungsi-fungsi manajemen POAC (Planning, Organizing, Actuating, and Controlling) yang tertuang dalam pembuatan program kerja yang disesuaikan dengan unit/bidangnya.

Kemampuan membuat sebuah program kerja bagi seorang manajer dalam menjalani fungsi manajerial sangatlah dibutuhkan, karena seorang manajerial dituntut bisa mengatur, kegiatan-kegiatan yang menyangkut perencanaan, pengorganisasian, pengarahan pengawasan usaha para anggota-anggotanya (bawahannya) agar bekerja dengan baik dan memiliki penetapan tujuan (goal setting) yang jelas, agar program kerja yang dibuatnya dapat terlaksana dengan baik. Menurut Dubrin (Lunenburg, 2011) manajer yang membuat goal setting yang jelas, cenderung akan meningkatkan dan mempertahankan kinerjanya dengan baik. Hal ini selaras dengan pendapat Locke (1990) karyawan yang memiliki goal setting akan lebih tekun, bersemangat, lebih tahan dan memiliki ambisi yang lebih tinggi dalam mencapai tujuan kinerja yang lebih baik.

Menurut Kinicki dan Kreitner, (2004). Pentapan tujuan (goal setting) memiliki empat 
mekanisme dalam bekerja yakni dengan adanya penetapan tujuan dapat mengarahkan perhatian individu untuk lebih fokus pada pencapaian tujuan tersebut, kedua tujuan akan dapat membantu mengatur usaha yang diberikan oleh individu untuk mencapai tujuan, ketiga adanya tujuan dapat meningkatkan ketekunan individu dalam mencapai tujuan dan keempat tujuan membantu individu untuk menetapkan strategi dan melakukan tindakan sesuai dengan yang direncanakan.

Goal setting tidak hanya memberikan panduan untuk melakukan pekerjaan, tetapi goalsetting juga membantu individu untuk membangun dan menguatkan perasaan efikasi diri. Hal tersebut sejalan dengan pendapat Applebaum dan Hare (1996) yang menyebutkan bahwa goal setting dapat menstimulasi tindakan dan usaha, sebagai standar kemampuan preformasi yang dapat diukur dan sebagai panduan rasa efikasi diri.

Goal setting merupakan faktor penting dalam bekerja, faktor tersebut timbul karena segala maksud untuk bekerja manuju suatu arah tujuanyakni tujuan memberitahu karyawan tentang hal yang perlu dikerjakan dan betapa banyak upaya yang dilakukan, sedangkan efikasi dirimerupakan keyakinan terhadap diri sendiri mengenai seberapa besar kemampuan dalam mengerjakan suatu tugas tertentu yang pada akhirnya akan mempengaruhi pola pikir dan kekuatan untuk bertahan dalam menghadapi tugas tersebut.

Pada pelatihan ini manajer tingkat menengah mendapatkan pemahaman untuk mengenali dan merumuskan tujuan dengan jelas yang langsung mengarah pada sasaran (tujuan spesifik),dengan tujuan yang spesifik dapat mengarahakan manajer tingkat menengah untuk mengetahui apa yang akan diraih dan menjadi tolak ukur atas sasaran yang ingin dicapai. (Locke dan Latham 2002).

Manajer tingkat menengah mampu untuk membuat tujuan yang menantang atau sulit dengan memprediksi hal-hal yang akan dapat mendukung dan menghambat pencapain tujuan (kesulitan tugas). Menurut Bandura (1997) faktor utama dalam mencapai tujuan adalah efikasi diri karena dengan keyakinan internal yang dimiliki seseorang akan mempengaruhi individu tersebut meyakini bahwa ia mampu mencapai tujuan yang ingin dicapai.

Manajer tingkat menengah mengetahui tentang pentingnya menetapkan tujuan dan usaha untuk menyelesaikan pencapaian tujuan dengan kebulatan tekad dan inisiatif untuk menyelesaikan pencapain tujuan yang telah dibuatnya (komitmen terhadap tujuan). Serta manajer tingkat menengah juga memahami proses dimana individu diarahkan untuk memberikan dan menerima umpan balik(feedback), dimana umpan balik ini merupakan informasi yang berisi tentang bagaimana suatu program kerja bisa dijalankan dan dievaluasi dengan hasil yang relevan. Keikutsertaan manajer tingkat menengah dalam berpartisipasi menyusun dan merencanakan tujuan sehingga peserta tahu bagaimana strategi untuk penyelesaiannya. Menurut Casio (1987) dengan adanya goal 
setting dapat lebih mengarahkan tingkah laku untuk mencapai tujuan, goal setting dapat memberikan penjelasan atau informasi kepada tenaga kerja bagaimana mengerjakan suatu tugas, serta mengapa sasaran atau tujuan tersebut penting dilaksanakan. Selanjutnya penelitian Lawrence dan Smith (Arsanti, 2009) menunjukkan bahwa kinerja dari para pekerja akan lebih meningkat secara signifikan apabila mereka berada pada kondisi kerja dengan penetapan tujuan dari pada tanpa ada penetapan tujuan, dengan demikian keberadaan penetapan tujuan (goal setting) menjadi sangat penting ditempat kerja.

Pada pelatihan Goal setting ini manajer tingkat menengah memperoleh pemahaman dan pengetahuan tentang bagaimana menyusun program kerja dengan tujuan yang jelas sebab dengan tujuan yang jelas dapat memberikan arah dan fokus yang lebih terperinci bagi manajer tingkat menengah didalam melaksanakan tugas manajerialnya, pokok pembahasan dalam pelatihan goal setting ini memberikan gambaran bahwa tujuan itu akan dibuat lebih spesifik, dapat diukur, mudah diraih berfokus pada tujuan yang ingin dicapai sesuai dengan kemampuan dan keterbatasan diri, serta tujuan itu harus dicapai sesuai dengan batas waktu yang ditetapkan.

Menurut Kreitner \& Kinicki, (2004)dengan adanya tujuan akan mengarahkan perhatian seseorang untuk fokus pada satu perhatian pada apa yang relevan dan penting, selain itu dengan adanya tujuan akan mengatur usaha dan juga memotivasi untuk bertindak dengan efikasi diri yang tinggi, tujuan juga akan meningkatkan ketekunan untuk menyelesaikan tugas tertentu. Orang yang tekun cenderung melihat hambatan sebagai tantangan yang harus diatasi dari pada sebagai alasan untuk gagal sehingga efikasi diri sangat mempengaruhi individu dalam menentukan sikap dan mencapai tujuan atau goal yang ingin dicapai, tujuan akan membantu mengembangkan strategi dan rencana tindakan, dimanatujuan dapat membantu mendorong orang untuk mengembangkan strategi dan rencana aksi yang memungkinkan mencapai tujuan atau goal setting yang akan mereka lakukan

Hasil evaluasi manajer tingkat menengah setelah mendapatkan pelatihan goal setting ini terlihat bahwa tingkat efikasi diri peserta terutama pada aspek kesulitan tugas (magnitude) seluruh peserta pelatihan manajer tingkat menengah mulai melaksanakan program kerja yang dibuatnya meskipun ada keterbatasan sarana dan parasarana serta SDM yang ada, sedangkan pada aspek luas bidang tugas (generality) peserta merasa cukup mampu jika dihadapkan pada tugas yang beragam maupun tugas diluar unit kerjanya, dan apabila mengalami konflik peserta akan berusaha mencari solusi untuk mengatasi konflik tersebut.

Pada aspek kemantapan terhadap keyakinan (Strength), peserta merasa yakin dapat menyelesaikan pekerjaan sesuai dengan target yang sudah dibuat, dan yakin bisa menyelesaikan lebih cepat dari waktu yang sudah ditentukan dan berusaha konsisten untuk melaksanakan pekerjaan dengan sebaikbaiknya, terlihat bahwa kanit dan kabid sudah mulai memahami cara pembuatan program 
kerja yang jelas dengan pola kerja yang mulai teratur dan jelas dan sudah memiliki perencanaan jangka pendek dan jangka panjang (memiliki tujuan spesifik/jelas) kanit atau kabid dalam memberikan tugas atau perintah kerja cara yang jelas dan terarah, ikut berpartisipasi serta berkomitmen untuk mencapai tujuan serta melakukan evaluasi (feedback) terhadap program kerja yang dibuat. Dengan demikian tujuan dari pelaksanan pelatihan ini dapat tercapai, melalui pelatihan ini manajer dapat membuat goal setting yang lebih baik, manajer dapat membuat program dengan spesifik, jelas, dapat terukur, mudah diraih, dan berfokus pada tujuan yang ingin dicapai sesuai dengan kemampuan dan keterbatasan dirinya. Melalui pelatihan goal setting ini manajer dapat menentukan sikap dan tindakannya, serta mampu mengambil keputusan dengan penuh keyakinan dalam menghadapi tugas yang beragam, merasa yakin terhadap kemampuan yang dimiliki, sehingga jika dihadapkan pada tugas-tugas yang sulit, dapat lebih mantap dan yakin pada saat melaksanakan perannya sebagai seorang manajer tingkat menengah

\section{KESIMPULAN}

Berdasarkan hasil peneilitian dan pembahasan dapat disimpulkan bahwa ada perbedaan tingkat efikasi diri antara kelompok eksperimen yang mendapat perlakuan berupa pelatihan goal setting dan kelompok kontrol yang tidak mendapatkan perlakuan (pelatihan goal setting).
Melalui pelatihan goal setting ini ditujukkan agar terjadi peningkatan efikasi diri manager tingkat menengah terhadap kemampuan manajemen skill terutama dalam pembuatan program kerja sehingga dapat membuat program kerja yang lebih spesifik dan terarah, dapat diukur, mudah diraih berfokus pada tujuan yang ingin dicapai. Dengan memahami kemampuan membuat tujuan yang jelas maka manager tingkat menengah akan memperoleh pengetahuan dan keterampilan yang membantu dirinya dalam bertindak dan mengambil keputusan secara cepat dan tepat, serta dapat meningkatkan efikasi dirinya terutama dalam bidang manajemen skill (planing, organizing, actuating, controling) yang tertuang dalam pembuatan program kerja yang jelas yang dapat mendukung tercapainya tujuan perusahaan.

\section{DAFTAR PUSTAKA}

Azwar, S. 2010. Metode penelitian. Yogayakarta: Pustaka Pelajar.

Applebaum, S.H., \&Hare, A. 1996. Selfefficacy as a mediator of goal setting and performance some human resoure applications. Journal of Managerial Psychology. 11, (3), 33-47

Anoraga, P. \& Suryanti, S. 1995. Psikologi Industri dan sosial. Jakarta : Pustaka Jaya

Arsanti T.A,. 2009. Hubungan antara penetapan tujuan, self-efficacy dan kinerja. Jurnal bisnis dan ekonomi ( $J B E)$. 16,(2), 97-110

Bandura, A. 1985 Social foundations of thought and action; social cognitive theory. Englewood Cliff, NJ; PrenticeHall. 
Bandura, A. 1997. Self efficacy: the exercise of control. New York: W.H. Freeman and Company.

Corsini, J. \& Marsella, J. 1983. Personality Theories Research and Assesment. Itaca: F. E. Peacock Publishers. Inc.

Gibson, G.B. 2001. Me and us : diferential relationship among goal setting training efficacy, and team level. Journal of organizational behavior, 22, 789-808

Halonen. J.S. \& Santrock, J.W. 1999. Psycology : Contexs and Aplication, Edisi Ketiga. New.York : McGraw Hill.

Irmawati, 2004, Peranan goal setting dalam upaya meningkatkan produktifitas kerja karyawan, Universitas Sumatra Utara.

Kirkpatrick. 2007. Implementating the Four Levels: A Practical Guide for effective Evaluation of Training Program. San Fransisco: Berret-Koehler Publisher, Inc.

Kartono, K. 2003. Psikologi sosial untuk manajemen perusahaan dan industri. Jakarta: PT Raja Grafindo Persada.

Kreitner, R \& Kinichi, A. 2001. Organizational Behaviour. (Fith Edition). New York: MC Graw-Hill

Locke E. A, \& Latham G. P. 1985. The application of goal setting to sport. Journal of Sport Psychology. 1, (1 ), 205-222

Locke E.A, \& Latham G.P. 1990. The application of goal setting and task performance. Engewood Cliffs, NJ: Prectice Hall

Latham, G.P \& Locke, E.A. 1994. Cognitive and motivational effect of participation; a mediator study. Journal of organizational behavior.15,(1), 49-53

Locke E.A \& Latham G.P. 2002. Building practically useful theory of goal setting and task motivation. American Psykology, 57 (9) 705-717
Lunenburg, 2011. Goal setting theory of motivation. Journal of management, busineess and adminitration. 15 (1). 16

Noe, R.A. 2002. Employee training and development. New York: Mac GrowHill

Nitisemito, S. 1992. Manajemen Personalia. Jakarta: Sasmita Bros.

Robbins, Stephen P.1998. Organizational behavior. New Jersey: Prentice-Hall, Inc

Ramadhanti, F.H. 2010. Hubungan self efficacy dengan goal setting karyawan. PT. Humeria Semata. Skipsi. UIN Syarif Hidayatullah. Jakarta

Sulistiorini, 2009. Manajemen Pendidikan Islam, Teras : Yogyakarta,.

Sutama. P.E.W. 2012. Pelatihan penetapan tujuan untuk meningkatkan selling efikasi pada wiraniaga. Skripsi. Univesitas Gadjah Mada

Suranta, S. 2002. Dampak motivasi keryawan pada hubungan antra gaya kepemimpinan dengan kinerja karyawan perusahaan bisnis. Jurnal empirik. 15 (2) 116-138

Segal, G.\& Jerry, S. (2005). Self efficacy and goal setting as predictors of performance: An empirical study of faouder natural food stores.

Journals of Business and Entrepreneurship. 17 (1), 243-256

Spieker, C. \& Hinsz V. B. 2004. Repeated success and failure influences on selfefficacy and personal goals. Social behaviour and personality. 32. (2) 191-189 